Trade Routes between British Burmah and Western China; with Extracts of Letters from

\title{
Mr. Margary
}

Author(s): J. Coryton and Mr. Margary

Source: Proceedings of the Royal Geographical Society of London, Vol. 19, No. 4 (1874 1875), pp. 264-291

Published by: Wiley on behalf of The Royal Geographical Society (with the Institute of British Geographers)

Stable URL: http://www.jstor.org/stable/1799707

Accessed: 27-06-2016 08:40 UTC

Your use of the JSTOR archive indicates your acceptance of the Terms \& Conditions of Use, available at

http://about.jstor.org/terms

JSTOR is a not-for-profit service that helps scholars, researchers, and students discover, use, and build upon a wide range of content in a trusted digital archive. We use information technology and tools to increase productivity and facilitate new forms of scholarship. For more information about JSTOR, please contact support@jstor.org.

The Royal Geographical Society (with the Institute of British Geographers), Wiley are collaborating with JSTOR to digitize, preserve and extend access to Proceedings of the Royal Geographical Society of London 
ceedings of Conference of Maritime Meteorology, 1874 (The Meteorological Committee). Reproduction in photolithography of letter from Godinho de Oredia (The Secretary of the Portuguese Legation). Italy: Handbook for Travellers; by K. Baedeker, 3rd part, 1875 (Editor). Results of Observations made at the Radcliffe Observatory in 1872, vol. xxxii. (The Radcliffe Trustees). J. B. Biot's Tafeln neu berechnet von H. Kiefer, and Inhaltsverzeichniss zum Bibliotheks Katalog des Tiflisschen physikalischen Observatoriums, von $\mathrm{H}$. Kiefer, 1874 (The Tiflis Observatory). Discursos, \&c., del Señor Don Francisco Coello y Quesada, 1874, and Noticias sobre las vías, \&c., de la epoca romana en la Provincia de Álava; por F. Coello y Quesada, 1874 (Señor Quesada). Météorologie nautique, No. 532 (Dépôt des cartes et plans de la Marine); and the current issues of corresponding Socities, \&c.

Donations to the Map-Room since the last Meeting of March 8TH, 1875. - Season chart of the World, with the differences of Time East and West of Greenwich, and the approximate monthly rainfall of either hemisphere, showing also the Chief Ports and Routes of Commerce throughout the Globe. Map of Australia and New Zealand, with the Fiji Islands. The British Colonies and adjacent territories in South Africa (S. W. Silver, Esq.). A map of the North-eastern Frontiers of Persia, embracing also Khiva and the intervening Deserts. Published for the 'Journal of the Royal United Service Institution' (Council of the Royal United Service Institution). Hypsometrical map of the Oberlechthaler Alps, Rhatikon Chain, and Silvretta Group. Map of the Central part of the system of the Thian-shan Mountains. Map of the highest region of the Himalaya Mountains. Map of the Argentine Republic, Chile, Uruguay, and Paraguay. Kerguelen Island (Dr. A. Petermann).

The following paper was read by the author:-

Trade Routes between British Burmah and Western China. By J. Coryton.

Ever since the opening of the Canal at Suez the question of a direct road from the Bay of Bengal to Western China has been receiving increased attention. The revolution achieved by the use of steam, now in general use in Eastern waters, has rendered us impatient of delay in travel; the merchants of India and IndoChina declare their ports to be suitable emporia for China trade, and merchants at home listen willingly to any schemes by which the dangers of the China seas are to be eliminated from their calcu- 
lations. Although the subject in this form has but recently attracted the attention of the public at home, the Government of India has, for the last half century, omitted no opportunity of gaining an insight, through actual inspection by competent officers, into the disposition and resources of neighbouring States, and the facilities afforded by the formation of the country for the establishment of routes which should "tap" Western China.

In the absence of regular surveys of the country it is proposed to cross, we must still rely on history for our conviction that no obstacles arising out of the physical conformation of the country exist. For five centuries, if we can credit the Chronicles of Ava, trade was maintained between Burmah and China by way of Bhamo, and enormous armies have from time to time swept, in their career of devastation, along the very tracks we are hoping to see traversed by caravans of traders. Our ignorance of the physical character of the broad belt of country we are desirous of traversing. is therefore of small mornent, and our maps give us, no doubt with sufficient accuracy, the position of the leading mountains, rivers, and towns. It is our ignorance of the political status of the population we have to deal with that constitutes our real hindrance, and has hitherto caused the failure of our attempts. Those who know the care with which official returns are prepared by the Indian Government will understand how utter that ignorance is, when they learn that until last year the form containing the particulars of our political relations with neighbouring States was sent by the Local Government in blank, fur the simple reason that the British authorities were unable to say who their neighbours were. An article in to-day's 'Times,' showing how, under one of the ablest administrators of our day, Sir Arthur Phayre, "some 1000 square miles" were excluded from British sovereignty "by some error" in a map compiled by officers of great Indian experience, will do more to suggest the origin and extent of this chaos in our geographical knowledge than anything I could say.

Now it so happened that it was my duty for some years to speak with authority - I will not say with confidence-on this very subject. of the geographical boundaries of States adjacent to British Burmah. In the Court of the Recorder of Moulmein, suits were continually before me involving rights to timber felled on the banks of the Salween, far above British jurisdiction. Each party claimed to have acquired his rights by purchase from the Forest Chief. Finding the difficulty in which I was left from all official recognition of neighbouring states embarrassing, I stated a case for the opinion of the High Court of Calcutta; and the opinion of that 
Court was that I was bound to determine, as a fact, who was sovereign in the locality in which the timber had grown. The result of having to take judicial cognizance, for this purpose, of the petty skirmishes constantly occurring in the forest districts where the rudest state of society prevails, was, as may be supposed, occasionally absurd. In one case, a forest chief, to make his sovereignty (which I think I had declared established) the more unquestionable, sent to Moulmein, and had a hand-stamp manufactured with his titular honours; and this he was in the habit of affixing, after the fashion of a sign-manual, to documents evidencing the purchase of timber felled within his territory. As a rule, it would be difficult to define these petty sovereignities more exactly than by saying that the chiefs admit in every case some sort of allegiance either to China, Burmah, or Siam, and, as was evident from the careful records of the exploration on the Mékong in 1868, not unfrequently to more than one at the same time.

There is one characteristic of the people inhabiting the belt of country we are considering, which tells either in favour of or against our scheme in precise proportion as the country is tranquil or disturbed. I refer to their love of a wandering life, which makes of the Shan an admirable trader when law and order are prevalent, but a very unpleasant neighbour in cases where the country is unquiet. One of the great objects of our Government in Burmah has been to counteract this restless spirit; and in his last Report, the Chief Commissioner of British Burmah notices with satisfaction the fact that the hill-tribes of Northern Aracan had been undisturbed by the raids of trans-frontier tribes during the year, and that the condition of the tribes within our territories had continued to improve, in consequence of the comparative quiet there existing.

"Our relations with the tribes beyond our administrative frontier," the Report says, "improve year by year. The Koons, formerly the most troublesome tribe in our neighbourhood, are now engaged in friendly intercourse and trade with our people. Messengers arrive during June from the Shindoos, who inhabit a tract of land considerably to the north of the Aracan tracts, and they express a desire to enter into friendly relations with the Superintendent. There is, in fact, every reason to think that the principles laid down three years ago for the adminstration of these hill-tracts are proving very successful in their practical results. Our own subjects are devoting themselves to agriculture, and they obtain a ready market for their tobacco, cotton, and garden produce, while we hold out every inducement to the tribes beyond 
our boundary to abandon their present restless life, and turn to trade and barter."

Mingled with the motley population of Shans, in the belt of country south-west of Yunan, is one element of which we may regard the increase in the neighbourhood of Bhamo and Mandalay with great satisfaction. I refer to the Chinese, who, having left their country as emigrants from the Eastern ports, have gradually established themselves as coolies, cultivators, and traders along the coast of the Malay Peninsula from Singapore to Rangoon, and so up the Irrawaddy to the very spot to which we are hoping their brethren will come overland to meet and trade with them.

'To the obstacles arising out of this political chaos existing outside Western China, we may add the utter disruption of society within it, the consequence of Civil war. In 1855 the Province of Yunan rose in rebellion, and sustained its independence under a Mussulman governor until 1873. During the period of this rule, bands of marauders, under petty chiefs, devastated the country on the frontier, and harried the few unfortunate traders that crossed their path to an extent which threatened to annihilate all trade.

If Tali, the citadel capital of Western Yunan, to which almost all the routes converge, be, as has been supposed, the Yachi of Marco Polo, the character and religious belief of its inhabitants have been for centuries in opposition to that of the rest of China. Writing in 1595, he describes them as a mixture of "idolatrous natives, Nestorian Christians, and Turks." During the last few years of Sultan Soliman's independence, Tali was the centre and key of the rebel power. Soon after the outbreak of the rebellion, the Mussulman troops attempted to push their successes southwards, but met with a repulse from the Tsaubwa of Kiang-tong, and retreated, laying waste the towns of Esmok and Yunan Sen. For ten years the rebel power was confined to the northern portion of Yunan. 'It was at this time, just as fresh exertions were being made to extend it southwards, and we ourselves were prepared to believe that the rule was permanently established, that it suddenly collapsed. Mr. Margary, writing from Talifoo, on the 18th December, announced his entry into that town, with the sanction of the authorities of Imperial China. "I am elated," he writes, " at my success; I have opened Talifoo, and vanquished the dragon which guarded its gates." In a former letter he had given a sad picture of the desolation produced by the long-protracted war.

We come now to the natural features of the country we are to cross. The plateau of Yunan, which is between 5000 and 6000 feet 
above the sea-level, is intersected by streams which, in their course, acquire the names of the Irrawaddy, the Salween, the Menam, the Mékong, and the Sonkoi. To the north are the huge barriers of "terrific snow-clad mountains" (as they are termed by the only Englishman who has probably ever crossed them), which preclude all ordinary intercourse between China and Thibet.

Having thus noticed the general condition of the country and the people we have to deal with, I will mention, in an order from west to east, the routes that have been attempted or proposed. 'These routes are very numerous, but may be divided into thirteen groups :-

1. Cooper's project for entering Thibet from the Brahmaputra.

2. From Sudiya on the Brahmaputra to Bhamo.

3. Route from Calcutta to Bhamo viâ Munipoor.

4. Akyab route to Mandalay.

5. The Irrawaddy route to Rangoon.

6. Sprye's route from Rangoon to Kiang Hung.

7. Route through Tonngoo to Rangoon by canal and rail.

8. Various routes starting from Moulmein.

9. The valley of the Menam.

10. The Mékong.

11. The Sonkoi.

12. The Sikiang.

13. The attempts from Shanghae to march directly westward on Talifoo and Bhamo.

First in this order we come upon the track of a very indefatigable labourer in the establishment of trade-routes. In $1870 \mathrm{Mr}$. T. T. Cooper, who had been struck on a previous visit to Thibet with the opening that country offered to the tea-planters of Assam, determined to proceed by the way of the Brahmaputra to the southern borders of Thibet, at the extreme east of which he hoped to find means of turning south and getting through Tali to Burmah. Passing up the Brahmaputra as far as Debroogur, Mr. Cooper skirted the river among the Mishmee Hills until, prostrated by fever at Puna, he was compelled to retrace his steps and abandon his design.

Other projects have been formed, and attempts actually made, to reach China from Assam by the more southerly routes from Sudiya, on the Brahmaputra. Those desirous of following in detail the steps taken by order of Government for this purpose, will find much that will interest them in a selection of papers regarding the ' Hill Tracts between Assam and Burmah,' printed at the Bengal Secretariat Press in 1873. In the year 1826, Messrs. Wilcox 
and Boulton, starting from Sudiya, passed along the valley of the Nam Lang to the town of Manche, the head-waters of the Irrawaddy. They were unable to reach any point eastward of Manche, and though within twenty miles of the meridian at which the survey of the Jesuit missionaries of Yunan had just terminated, were compelled by the jealous vigilance of the Burmese authorities to return without having been able to traverse the intermediate space. The subsequent researches of these officers, together with those of Captains Bedford and Neufoille, have done much, however, to dispel the mist that had previously rested on that locality.

The route said to be most in favour with the Calcutta merchants is that which it has been proposed to make in a direct line from Dacca through Sylhet and Munipoor to Bhamo. Of all these routes having Calcutta for their base, we may safely say that they are premature, and can only be usefully surveyed when Bhamo, the point for which they all make, has become the end of a road which is clear of obstructions into China.

The same remark applies to Chittagong, which, although favourably situated in other respects, has too little water to play an effective part as a terminal port.

The pretensions of Akyab have been strongly urged, and the Society is indebted this evening to a prblic-spirited member of the mercantile community of that port for the map before it. Mr. J. O. Hay thus sums up, in a letter recently addressed to the Associated Chambers of Commerce of the United Kingdom, the advantages of bis route. That the line from Akyab to Mandalay is the shortest; that Akyab is the finest port in the Bay of Bengal; that the line will pass through a country rich with coal and iron, and producing cotton, tobacco, tea, indigo, \&c., in abundance. Admitting the excellence of the port, I fear that for the present, and until the route by way of Rangoon is brought into successful operation, the great range of the Yomadoung Hills, the lowest pass of which is over 4000 feet in height, will cause the consideration and the claims of Akyab to be postponed.

We come next to the Irrawaddy with its ports of Bassein and Rangoon. The adoption of either of these ports is a mere detail in the Bhamo scheme, and I shall consider it therefore with reference to Rangoon. The route by the Irrawaddy follows the course of that river from Rangoon to Bhamo, a distance of between 600 and 700 miles, and passes thence by way of Manwyne and Mômein or Tengyechow to Talifoo. The following extracts from the last Administrative Report issued by the Local Government of Burmah, set out the reasons for which this route has been selected for its support. 
"Since the suppression of the Panthay rebellion, the commercial intercourse between the province of Yunan and Bhamo is steadily increasing, and the Chinese firms in Rangoon are establishing branches at the last-named mart. The Burmese Government seem inclined to run their steamers between Mandalay and Bhamo; and, indeed, from all sides it is apparent that this route, the traditional western entrance into China, is destined to develope far beyond its condition at any previous point in history. The Rangoon and Irrawaddy State Railway, for the construction of which sanction has been accorded by her Majesty's Secretary of State, comes most opportunely as the most fitting exhibition of the determination of Government fairly to take in hand the thorough establishment of rapid and direct communication between the coast and the great inland markets."

The town of Bhamo, which serves as the starting-point of the route, is on the left bank of the Irrawaddy. If tradition is to be trusted, the place has before now been the scene of busy English trade. From inquiries on the spot, Mr. Bayfield was induced to consider there might be truth in the popular tradition which identifies an old ruin a day's march to the north-east with a factory established by the English somewhere in this neighbourhood, as early as the seventeenth century.

This route, as far as Bhamo, may be said to be all that can be desired. The steamers of the Irrawaddy Flotilla Company make the journey from Rangoon in nine days and return in four. The difficulties of the route consist, as we have learned by experience, in the liability to attack by the tribes bordering on it between Bhamo and Mômein. If Major Sladen, who had good opportunities of judging, is to be relied on, " 130 miles of railway between Bhamo and Mômein would effectually tap the resources of Yunan." The direct distance between Bhamo and Mômein is given at 122 miles, so that the railway spoken of, if feasible, could not be said to be one of uncommon deviation. Beyond Mômein we need hardly trouble ourselves with the question of communication, that town being connected with the principal towns of China by paved roads.

The history of the two expeditions we have despatched by this route is well known. Major Sladen's expedition in 1868 was for a long time detained by the hostility of a Kachyen chief in Ponsee, a village 10 miles westward of Manwyne. In Manwyne itself he was hospitably received, and was welcomed by the Mussulman Governor in Mômein, at that time in rebellion against China. From that point he retraced his steps, and no further action was taken 
until the expedition of the present year, organised under Colonel Browne. The history of this expedition, after its starting, is at present but imperfectly known. It was attacked at Manwyne by Chinese and Kachyens. Mr. Margary, a member of it, was killed. The rest of the party returned immediately afterwards to Rangoon.

The next route is that which leaves the Irawaddy at Mandalay, the present capital of Burmah Proper, and passing easterly along the valley of the Myit-gne, goes through Theebo and Theinnee to the Salween, which it crosses at Konglong, thence along the valley of the Nanting to Shunning and Talifoo. It was by this route that Colonel Browne was originally intended to have proceeded on his mission to Talifoo. It is traversed by numbers of traders every year, and being further from the dreaded Kachyens, has the reputation of being safer than either of the routes north or south of it. The eastern bank of the Salween through which this route runs, enjoyed during the existence of the Panthay kingdom an excellent reputation for order. A party of Panthays, who visited Moulmein in 1870, enlarged much on the tranquillity of this route. One of them, in speaking to me of it, threw down his wallet, and said, "There, I would leave it so in any part from Kiangma to Mounting."

Of the Sprye route, from Rangoon to Kiang Hung, no one who reads the records of the Mékong expedition can doubt that its terminal point in China is admirably selected. The obstacles offered by the character of the country are, however, very great. In his report to the Glasgow Chamber of Commerce, Mr. Findlay, who has been a great traveller in Burmah, expresses himself as decidedly adverse to it on the score of difficulties of construction. "I have seen," he says, " something of the country through which this (viz., the railway from Rangoon to Esmok) would have to pass, and can say, with full assurance, that a less promising field for railway enterprise it would be difficult to imagine.

"The line proposed would have to cross four great rivers, the Sittang, the Salween, the Menam, and the Mékong, or Great Cambodia, and no one can say how many tributary streams. Besides this, the valleys of these rivers are separated from each other by numerous ranges of hills which, in some places, might be more properly called mountains-frequently remarkable for their steepness-covered with jungle to their summits and utterly uninhabited, or, if at all, most sparingly so.

"I have no hesitation in saying, from what I have heard and seen of the country in question, that the scheme is in every point of view impracticable, even if the valleys were much more thickly inhabited 
than they are. I would further observe, that if a railway ever enters China from Burmah or Bengal, it will be by following, as far as possible, one of the valleys of the great rivers, and that it is in vain to think of doing so by repudiating the facilities offered by these, and attempting to drive a railway across them in spite of every natural difficulty and obstacle."

I should pass over the Sittang altogether as a trade outlet, were it not for the measures now in contemplation by the Local Government to draw off the very considerable trade of Tongoo on the north-east frontier of British Burmah, by a canal and railway to Rangoon. The river itself can never be utilized for our purpose, since, owing to the peculiar formation of the head of the Gulf of Martaban, it is subject to a tidal bore which renders the Sittang: unapproachable from the sea. The tidal creek, moreover, which connects the Pegu River with the Sittang being open only at spring tide, the Shan trader at Tongoo, only 160 miles from Rangoon, finds himself as distant from his market as the Chinaman at Bhamo, which is 700 miles from Rangoon.

I come next to Moulmein on the Salween (or, as it is called in China, the Loo-kiang). This river, as you will see by the map, runs precisely in the direction of the traffic we are desirous of attracting. If the river were navigable throughout, or if its deficiencies could be supplemented by canals, or if a railway could be run along its banks, the question of the best route from Tali to the sea would soon be decided. It is unfortunately navigable only for about 120 miles from the port of Amherst, where the navigation is interrupted by the falls of the Kyodan, the height of which is about 30 feet in the cold weather, the river rising to this level in the rains. Beyond this point but little of this river is known to Europeans. It is marked in the maps as full of rocks and rapids, but these obstacles have been put in mostly from hearsay and by conjecture, since, notwithstanding the despatch of several parties with a view to its exploration, the upper part of the Salween has not been visited by anyone competent to survey it. I have been assured by natives from the neighbourhood of Moné, that it is navigable many days' journey between that town and Dahgwinzeik. The routes of the exploration parties of O'Riley, 1855-6; Barker, 1856-7 ; Watson, Sconce, and O'Riley, 1863-4; and Watson and Fedden, 1864-5, will be found on the map annexed to the papers relating to M'Leod and Richardson's famous missions, which I shall notice directly.

The notice by the Local Government in its Report of the traderoute leading from the Siamese Provinces on the Upper Cambodia 
through the tributary state of Zimmay, to the Tenasserim division of British Burmah, runs thus:- "Even from the lower provinces of China, produce finds its way by this route, and it is hoped that the commercial treaty lately entered into between the King of Siam and the Government of India, to develope and regulate the trade passing through Zimmay, may be attended with good results."

I have spoken already of the well-established trade, which it is a matter of history was formerly carried on between China and the ports of Burmah. In the first years of our occupation of the eastern part of what is now British Burmah, it seemed as if all we are now hoping for was actually made to our hands. Caravans of Chinese traders were at Zimmay, waiting only for an assurance of safeconduct to visit our newly-acquired port. On our part, the authorities at Moulmein were using every exertion to secure, by diplomatic negociations with Siam, the quiet of the district through which the traders had to pass.

A writer in the "Moulmein Advertiser' says :- "We believe that one of the objects of the mission is to remove the obstacles which appear still to exist to the free passage of the Chinese overland-caravans to Moulmein. This is indeed a most important object, and one that should not be lost sight of. The failure of the attempt to reach Moulmein last year must have tended greatly to discourage all future endeavours, and if, as is supposed, there exists a jealousy of this intercourse on the part of the neighbouring Shan States, it can only be overcome by the presence of a British officer furnished with a royal order for a free and unmolested passage to the Chinese. We can scarce expect, after what has happened, to see the Chinese down this season, but we trust all impediments will be removed from future journeys."

After stating that Dr. Richardson had been selected for the Mission, the writer proceeds :-

"Dr. Richardson is so well known among the Shan States that we feel convinced, should he succeed in reaching them direct from the capital of Siam, furnished with orders for the removal of all impediments to the journey of the Chinese, we shall have them here at the close of the next year in considerable numbers, and it may be eventually that Moulmein will become an emporium for the export of tea. Captain M'Leod found it extensively cultivated between Kyain-Tung and Kyain-Hung, whence it is carried into the Chinese Provinces ...."

In the interesting "Papers relating to the route of Captain W. C. M'Leod from Moulmein to the frontiers of China, and the route of Dr. Richardson on his fourth Mission to the Shan 
Provinces of Burmah,' printed by order of the House of Commons, in 1869, we find records of journeys by the officers of British Burmah, which, neither for extent nor importance of results, have been since ever equalled.

"I found," says Dr. Richardson, describing what he saw at Zimmay, in 1829, "the caravan of Chinese traders consisting of 200 mules and horses. Three hundred more were said to be at Moung-Nan, where cotton is abundant. They had arrived in the country a considerable time before me, and were preparing shortly to return home. I had a good deal of conversation with two heads of caravans, who seemed to be intelligent, enterprising characters. They said they had long entertained the idea of visiting Moulmein, and now that they were invited to do so, and were assured of protection, they would undoubtedly do so next season, the present one being too far advanced to allow of their increasing their distance from home. They requested that an interpreter should meet them at Zimmay; and from their repeated requests that he should be at Zimmay in November, in order to accompany them down, I feel convinced that this people will be at Moulmein before the end of the year."

The disposition of the chiefs through whose territory the caravans would have to pass, Dr. Richardson speaks of as most favourable. "I found," he says, " no difficulty whatever in obtaining their consent to their passing through the country. No objection was ever hinted, nor have I reason to expect that any will hereafter arise."

As to the conditions under which, if we are successful, our first trade in this direction, will probably be carried on, the remarks made by Richardson on the caravans he fell in with on this occasion have much interest for us.

"The imports by these caravans consist of copper and iron vessels, silk (raw and manufactured), stains, gold and silver thread and lace, musk, walnuts, carpets, and vermilion. They export from the Shan country, cotton, ivory, skins, and horns. From the information which I could collect, the caravans assembled at Moung Koo, distant from Zimmay about two months' journey. Their goods are conveyed by mules, and they would appear to travel rapidly, as they asserted they would not be more than twelve days from Zimmay to Moulmein. They allow nothing to detain them on their journeys. If a man fall sick, or is disabled, he is left behind; and if one dies, they do not even stop to bury him, but cover his body with a cloth and continue their route."

The most important of these official journeys, however, so far as 
our present purpose is concerned, was that of Captain M'Leod, who, crossing the Thong-yeen in December, 1836, actually reached the frontier of China at Kiang-Hung, on the western banks of the Mékong. Beyond this point all attempts to progress were unavailing. He was told, if he insisted upon going on, the subject must be referred to the King through the customary channels, and an answer might be expected in about a year. Though within five marches of China, Captain M'Leod, knowing he would apply to the Court of Pekin in vain, determined on returning to Moulmein, and left Kiang-Hung on the 21st March. His return was far more expeditiously performed than his journey outwards. He reached Kiang-tung on the 31st, and found that orders had arrived from Moné, not to permit him to proceed until instructions had arrived from Ava. Quitting Kiang-tung on the 4th April, he arrived at Zimmay on the 19th. The authorities at Zimmay ultimately refused to permit our merchants to proceed by the road travelled by Captain M'Leod ; for such was their hatred of the Burmese that they would hold no communication with them. The Chinese even, who were on terms of amity with both nations, found themselves compelled to travel on the eastern bank of the Mékong, over high mountains, where the territories of Kiang-Hung adjoined those of Moung-Nan, one of the Shan States tributary to Siam.

From Zimmay, which he left on May 11th, M'Leod deviated from his former route, travelling seven days in a southerly direction, which brought him to within two stages of the town of Labong, where he crossed the Mépiu, and, striking off to the westward, reached the Thong-yeen in five days, and Moulmein by six further stages. The road he took, though circuitous, ran generally over low hills, and was in every way preferable to the route by which he had gone up, villages from which supplies were procurable being met with every second or third day. M'Leod describes the tribes, from the North of Zimmay to the frontier of China, as differing in their stages of civilization and in language, having no written character, no ideas of a Supreme Being. The mountains he saw were all thickly wooded, and abounded with wild animals and game of every sort.

The extent of the trade that now actually exists between the seaports of British Burmah and the interior will, I think, surprise those who are not acquainted with the subject by personal inspection. I was assured by Aga Syud, one of the leading native merchants of Moulmein, that the value of the piece-goods, with which our hardy visitors, the Shan pedlars, trudge back to their homes yearly, is not less than a lac $(10,000 l$.), while respectable 
Surattee merchants had assured me that it rarely falls below $30,000 l$., or two-thirds our entire imports of this class. The amount varies, no doubt, within large limits. Under favourable conditions, that is to say, when tranquillity prevails upon our frontiers, it attains considerable dimensions, while disturbances have an equally powerful effect in the opposite direction.

It is extremely difficult to obtain anything like trustworthy statistics with reference to the primitive trade thus carried on, the traders being apprehensive that if their profits were known to the Government, they would be subjected to taxation. The number of Shan residents, both in Rangoon and Moulmein, is very large, augmenting and decreasing in proportion to the tranquillity of the times. The numbers stood for Moulmein as high as 4859 in 1865 . Owing to the troubled state of the adjacent territory of Karennee, it fell shortly after to 966 .

Thinking it might be of interest, I have brought with me some silk and copper, which were brought into Moulmein, some four years ago, by a party of twenty-eight men, who had journeyed thither for a period of ninety days. I sent some of the silk to Calcutta, and mentioned the price at which it had been sold in the Moulmein bazaar. The quality was unknown in the Calcutta market, but the price was said to be very low. I may mention, as giving some key to the question of price, that the piece of copper before you, which is I believe of greater intrinsic value, was the exchange among these primitive people for an anna (1 $12 d$.$) . The$ hardy habits of the party of traders I am speaking of, were such as, even in a country where great simplicity of life prevails, to excite surprise. They slept during their stay with us in the open air; their large, pear-shaped baskets stacked round in a circle, after the style in which, as they informed us, they bivouacked nightly during their long wanderings. One of the officers of the British India Steamers, who accompanied me to visit them, said he felt confident from their general appearance that they were natives of Tonquin, and this opinion was subsequently confirmed to me at home by Mr. Cooper, who said he was familiar with the kind of silk they brought. As I was known to take much interest in such matters, the arrival of Shan traders that had come from extraordinary distances was usually announced to me by the Burmese; when possible I paid the people a visit, and endeavoured to get what information I could from them as to their routes. On the occasion of the traders I am speaking of coming in, I was called to see "Chopstick Shans," and found that half of them disposed of their food in this fashion, and the other in the manner usual with Burmese. On inquiry, it 
turned out that the little company was composed of two parties, who had come from different quarters, and met at about a month's march distant from Moulmein. Their routes are shown on a map made by themselves, which I have brought with me this evening.

Speaking of this and other similar maps, I an reminded of a peculiarity of the Shans which has not, I think, hitherto received attention. It is their almost instinctive recognition of time, direction, and distance-the result, no doubt, of a wandering life. The maps exhibited, and which I have much pleasure in presenting to this Society, have almost all been drawn by these pedlars themselves, usually in the verandah of my own house; the only assistance they received being that of the interpreters and lookers-on of their own parties. Those on canvas are copies kindly made for me by the Surveyor-General of India, Colonel Thuillier, in return for the originals, which, together with a set of valuable and elaborate maps which Mr. MacCall, of Todd Findlay's, was good enough to give me soon after my arrival in Moulmein, I had presented to the Government of India.

As an instance of the great distance traversed by Shan traders, I may mention the party of 54 men who were visiting Moulmein at the time that the late Viceroy, Lord Mayo, was making his tour of inspection in 1872. His Lordship spent nearly an hour before embarking in examining these men, who proved to be Panthays, who, starting from Maingshai in China, had reached Moulmein after a journey of 100 days, by way of Thein-nee, Tonngoo, and Martaban. They had traded in silk and gold-thread to Thein-nee, where they bought 100 horses, which they brought on to Moulmein for sale. They had, according to their account, passed through towns of considerable size. One great step will have been taken for the security of the traders, and the accommodation of the trade by this route, when we have bridged the Attaran. The scheme has often been contemplated; and the bridge proposed, as you may see from the accompanying map, is of very modest dimensions.

The next route in order, as we move eastward, is that of the Menam. This river is exceedingly difficult of navigation; and Bangkok, the capital of Siam, its port, has not water enough to satisfy the conditions of a great oversea trade. I shall not stay, therefore, to consider the prospects of this route, but content myself with recording the fact that on the 4th January, 1873, a treaty was concluded between the Government of Siam and the Government of India for the protection of life and property within the State of the Chief of Zimmay, through which the traffic

voL. XIX. 
of Moulmein from China has to pass. The treaty provides for the repression and punishment of robbers and marauders.

The route next in order eastward-a very promising one, if we judge of it by the map-is that of the Lan San Kiang, or Mékong. The merits of this route were recently tested by an expedition, the most memorable and instructive in the annals of exploration. The exploring party, headed by De Lagrée, the commander of a French gunboat, left Saigon in June, 1866, and after a visit to Pnom-peng, the new capital of Cambodia, began their arduous journey towards China. On the second day after leaving Pnom-peng the navigation became impracticable for the gunboat, and the party had to proceed in canoes. Had the object of this expedition been only to test the navigability of the river, it might have ended its labours here, for the river was full of rocks, dangerous even for canoes.

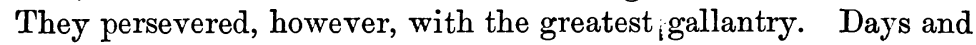
weeks went by, as they continued their slow and perilous passage. Provisions began to fail. Several of the party were ill. 'The guards became mutinous, and, in addition to all this, the floods, against which they had to struggle, were at times so violent that the boatmen found no other means of progress possible except that of clinging to the bank and pulling themselves along by the trees and bushes. " Our hold on the bank once lost," says De Carné, "the boat would be swept away by the current like a straw."

The observations of the writer of the interesting narrative of this exploration are so valuable with reference to the very points we are desirous of determining, that $I$ regret to be unable to give even the shortest summary of them. They include careful notes of the degrees by which the language, character, and political proclivities varied as they went on, until at Ham-gu they arrive at veritable China, find well-constructed bridges, and see women with crumpled toes. Before they reached that spot they had terrible sufferings to encounter, and at times must have almost despaired of their undertaking. At Barsae M. de Carné compares the relations of the potentate of that district with Bangkok to those of the Shan States of Burmah with Mandalay, and comes to the conclusion that the real politics of "the King," as he is called, is to profess allegiance to Siam, and do exactly as he pleases; a description which would suit, more or less accurately, a vast number out of the innumerable tribes scattered over this unknown country. The work is written with patriotic fervour, and records the dismay that came over the party when, wearied with a long day's work, they heard near Vien-Chan that before them was another exploring party, and that an English one. The next report 
announces the party as coming down the river, and the wearied Frenchmen prepare a hospitable welcome. When the "English flotilla" heaves in sight, they find that their laurels are in no danger. It turns out to be the equipage of a Batavo-Dutchman, land-surveyor and architect to his Majesty the King of Siam. Above Paclar, in $18^{\circ}$ N. lat., the party passed over the boundary of old Dutch explorations, and found themselves literally in terra incognita. The river at this spot, M. de Carné says, takes a bend for nearly 200 miles due west, a direction altogether contrary to that represented on the best maps. At Luang Prabang they discharged the pious office of erecting a monument over the remains of the famous and much lamented traveller Henri Mouhot.

Shortly after leaving Luang Prabang the party had an opportunity of settling a point on which geographers had disagreed. The Menam and the Mékong, namely, were known to approach each other very closely in this region, and it was supposed that they actually coalesced. A point of observation was soon attained from which it was seen that where they were nearest they were separated by a lofty mountain-range, on which a small crater of a volcano was active. At Kiantung the language had undergone a change, but the Laotian interpreter was still able to perform his functions. At a later stage the party had to depend for their communication with the authorities on the written character of the country, with which these Annamite attendants were familiar. This mention of written character reminds me of a circumstance that occurred when, in 1870, a party of Panthays were paying a visit to us at Moulmein. Being asked to write their names, some of them wrote them in Chinese and some in Burmese characters, using the latter not for the same sounds as they represent in Burmah-in fact, with so little resemblance to them as to induce me to believe that they had adopted them arbitrarily. Besides language and physical conformation, there were other than outward signs by which the party were able to gauge the extent of Burmese influence in these regions. At Luang Prabang the travellers noticed the prevalence of the Burmese habit of tatooing from the waist downwards - a practice which procured for the inhabitants of this province from the old Dutch geographers the title of " black-bellied Laos."

At Pales M. de Lagrée was "invited" by a letter from the Tsaubwa to continue his journey through Sien-tong. Neglecting this invitation, which was intended as a command, M. de Lagrée passed on to Samleap, in the State of Muong-You, and here difficulties thickened on him. The rains were at their height, and carriage transport was not to be had except at most inordinate 
rates. The party, however, gallantly struggled on, though each member of it was weakened by fever, dizzy with copious doses of quinine, and faint from the constant bleeding by the leeches, which form so terrible a scourge in Indo-China. Shoeless and ragged, the party arrived at last, across muddy plains and raging torrents, at Samleap.

At Muong-yong M. de Lagrée experienced the consequences of having refused the "invitation" of the Tsaubwa of Kiang-tung. The Governor of Muong-yong declared it impossible that persons guilty of such ill-breeding could be allowed to pass, and M. de Lagrée had to retrace his steps to Kiang-tung, learing his party at Muong-yong. His reception by the 'Tsaubwa was polite and courteous. No further obstacles were interposed to the continuance of his journey, and the whole party re-assembled at Muongyong. Here they were provided with boats, in which they continued their journey down the Namloi. Crossing a range of hills into the valley of the Nam-ga, they then came next to the town of Muong-tong, in the Kiang-hung State. The party were congratulating themselves on their improved prospects, when a letter arrived from Sien-hong with orders that, if the Europeans arrived, they were to return at once by the way they had come. For this unexpected and apparently arbitrary interruption to their progress it turned out that they were indebted to an excess of zeal for their safety on the part of their own countryman, the Vicar Apostolic of Yunan. 'Thinking it highly dangerous for them to prosecute their journey, that functionary had addressed a letter to the Viceroy of Yunan and induced that official to send a similar letter to Kiang Hung, and this had been construed by the latter as a prohibition to the party to enter China. The mistake having been explained, the Mékong was crossed for the last time 1200 miles from its mouth, and the precipitous hills which separate the plains of Yunan from the river having been surmounted, the party found themselves, on the 13th of October, 1867, sixteen months after they had left Saigon, in sight of the long-looked-for Esmok in Yunan. The suburbs were in ruins, the result of the civil war then raging. From the accounts which he received here of the state of Upper Yunan, M. de Lagrée judged further advance in the basin of the Mékong (here called the Kiong-lung Kiang, or " River of the Nine Dragons") impracticable. The condition of his party was now almost desperate. Their exchequer was all but empty. They were shoeless and in rags, and the health of all seriously impaired by the privations they had undergone. They had no interpreter, and had to communicate with the authorities through their Annamite. 
attendants, who still understood the written characters though not the langruage of the country. On leaving the basin of the Mékong the expedition directed its steps towards the Sonkoi, which it struck at the town of Yueng-Kiang. Here better days awaited them. Through Southern Yunan the passport of Prince Kung insured for them everywhere a hospitable reception, and guards and carriage were placed without payment at their disposal. The country is described as fully meriting all the eulogies it has received, and the weary wayfarers declared the scenery reminded them of Provence. The cultivation was everywhere admirable; while pine-forests, and mines of salt, coal, iron, and other metals, gave everywhere tokens of national wealth.

For upwards of a month M. de Lagrée traversed the southern portion of Yunan, visiting the large cities on his way to the provincial capital, Yunan-Sen. The officials everywhere received the party courteously, and the worst they had to suffer was from the intense and inconvenient curiosity of the populace as to the habits and customs of the "foreign devils," who were now for the first time seen in Yunan in their national costume. At Yunan-Sen the party was sumptuously lodged and entertained, and here they had the pleasure of meeting with their own countrymen in the persons of French Jesuit Missionaries of Yunan. The Governor violently opposed M. de Lagrée's project of visiting Talifoo before embarking. on the Yangtse for Shanghai. He could not believe that anyone could wish to visit the head-quarters of rebellion without being in league with the rebels. The address of M. de Lagrée triumphed at last over this opposition, and, furnished with a letter from the Grand Mufti of Yunan-Sen to the Sultan of Talifoo, the party started once more on their adventurous journey. The route it was thought best to adopt was a somewhat circuitous one through the southern part of Sze-chuen. They would thus approach Talifoo through a tract which, by the common consent of the rebels and Imperialists, had been left neutral ground, in order that the commerce of the Yangtze-kiang should not be interrupted. The party at length reached the valley of the Yangtse, where they were hospitably received at Tong-tchouen. Here M. de Lagrée became so ill as to be unable to proceed. Leaving one of the doctors with him, the rest of the officers, viz., Messrs. Garnier, Delaporte, Thorel, and De Carné, started on the 30th January, 1868, for Talifoo. Their way was through Hweli, from which town they advanced boldly into the rebel states under the guidance of a Chinese Catholic priest, Père $\mathrm{Lu}$, who conversed with them in Latin, but a Latin, as De Carné cannot help saying, (à "faire frémir,) " enough to make your 
flesh creep." The bands of robbers against whom they had been warned were not to be seen. At every place where Mussulman authority prevailed the letter of the Grand Mufti of Yunan-Sen procured them a cordial reception. At Pien-ho their progress was further assisted by another Chinese Catholic priest, whose Latin is declared to have been" absolutely unintelligible." In the same neighbourhood, however, they found a third (a French) Catholic priest who was most useful to them. Father Leguilcher had been living. in complete retirement, concealing his whereabouts as much as possible from the Mussulman authorities, whom he described as sanguinary and cruel tyrants, who, during the last ten years, had reduced the population of Yunan by one-half. At the sight of his. countrymen he courageously resolved to emerge from his retreat and accompany them to Tali as their interpreter. The party had now to lament the absence of their politic leader, whose admirable tact and savoir faire had carried them safely through so many perils. An unfortunate fracas in the streets of Talifoo brought their stay to an end. They had to retrace their steps to Hweli-chouen without exploring the city or the magnificent valley on which it is situated. To the French, therefore, belong: the honours of having been the first to reach the goal we have all along been aiming at.

The expedition returning to Tong-chuen found that their gallant leader had succumbed to a disorder produced by the toils and exposure he had undergone in the course of his long and painful journey, and the party descending the Yangtze-kiang, arrived with his remains, after an absence of two years, at Saigon.

The merits of the Sonkoi, which forms the next route, had, as we have seen, attracted the attention of De Lagrée on his journey of exploration of the Mékong, and it is to this river that the French have since the date of that exploration been chiefly directing their attention. M. de Carné speaks of the capabilities of this riverroute in the highest terms. The Civil war in Yunan, he says, " has in effect obstructed the ancient channel through which the products of Yunan flowed into the valley of the Irrawaddy, and opposes new obstacles to the re-opening of that road between China and India which is being sought for by the English with more obstinacy than good fortune. When one reflects that what is now required is to direct towards a French possession the products of that vast region, which, without including northern Laos, embraces four of the richest provinces of China, and to open out to us markets where the consumers are cpunted by millions, it must be admitted that a war of conquest and the opening of Tonquin is a 
necessary result of our establishing ourselves in the six provinces of Lower Cochin China."

The remarks of M. de Carné are endorsed in a very admirable article contributed by another traveller, Herr von Richthofen, to 'The Geographical Magazine' of January, 1874. In an admirably concise and lucid resumé of the whole question of trade-routes into South-western China, that gentlemen decides unhesitatingly in favour of the Sonkoi, with Mang-hau as the depôt on its head-waters.

On the 25th of October, 1872, the expedition of the Sonkoi started from Hong Kong under the command of M. Dupuis, a merchant of Hankow, and M. Millot, a merchant of Shanghai. It consisted of two French gunboats and a steam launch, freighted by the Titai Mah of Yunan with the materials of war. The expedition arrived off the mouth of the Sonkoi on the 9th of November, and moved up the river to Kechs or Hannoi, the capital of Tonquin, where it arrived on the 22nd of December, 1872. Tonquin was found to be in a state of political confusion, for the settlement of which M. Dupuis' good offices were put in requisition, and peace eventually restored. M. Dupuis left Hannoi on the 18th of January, and reached Laou Kai, the jast city in Tonquin, on the 20th of February. The Hong Kong papers, which reported the progress of the expedition, state that during the whole time the expedition was in Tonquin the Europeans experienced the best reception from the population, "who have the greatest desire to see the foreigners arrive to open their country and relieve them from the oppression" of the mandarins, who are regarded "with the bitterest contempt, and the deepest hatred."

Eastward again of all these routes is that by the valley of the Sikiang, with its seaport of Canton. This, as a saving of time or avoidance of perilous navigation, we need hardly consider.

With Shanghai we close the list of the ports of South-Eastern Asia in any way suited for the reception of the produce of SouthWestern China. From this busy centre of commerce the attempts have not been few to ascend the Yang-tse in its upper branches, and add to our knowledge of the country in that direction. I have time only to speak of two. Of him that has done the most, who has actually performed the feat, while others were nerving themselves for the attempt or recovering from the discouragement of failure, I say the least. Mr. Margary, attended only by his servants, left Shanghai last September and reached Bhamo in January of the present year. I will not attempt the panegyric or the lament of this accomplished traveller, in whom tenacity of purpose seems to have been so happily blended with 
affability of manners as to conciliate a notoriously suspicious and jealous population, and render his journey (with exceptions that only gave the zest of variety to his enjoyment--to use his own words)-a "triumphal progress." I have read in the papers many eloquent tributes to the memory of Mr. Margary; but I hardly know whether any have impressed me as conveying the sentiment we should entertain on such an occasion as forcibly as the simple remark of the Secretary of this Society, Mr. Major, when I informed him of the sad occurrence, "He has left us a noble legacy in his example."

The last traveller I shall mention is the gentleman whose exertions at the opposite point of the compass first engaged our attention, Mr. T. T. Cooper. Leaving Shanghai in 1868, Mr. Cooper on arriving at Ching-tu, the capital of Sze-chuen, assumed the native dress for the purpose of avoiding observation, and struck into the only route now in use out of the three formerly travelled from China into Mongolia, terminating at Lhassa, the capital of Thibet. His course was by way of Ta-tsian-too and Batang Atensee and Weeseefoo. At the latter place he was imprisoned, and on his release returned to Shanghai, whence he started for Calcutta on his tour I have already described.

While at Tai-tsian Loo, Mr. Cooper, writing to the editor of the 'North China Daily News,' thus expressed himself as to the project in which Bhamo is considered the natural outlet for trade from the districts of the Upper Yang-tse. " The present trade," he observes, " between Chunking and Yunan and Kweichau is only temporary on account of the closure of the Bhamo and Tah route, and as sure as this route is opened so surely will Burmah take to herself the trade of these two provinces; and if, as is probable, British merchants establish themselves at Ava, a rivalship for the trade of Sze-chuen between China and Burmah seems almost certain, the result telling probably in favour of the latter both in exports and imports. Trade by this route has flourished before without European enterprise, and as soon as it is re-opened the trade between Hankow and Chunking will be lessened one-third."

One can hardly conclude the subject without noticing, in a few words, the grandest of all the schemes for a direct route, viz., railroads such as Sir Macdonald Stephenson and others have proposed, either directly across Yunan by Talifoo or following the route proposed to himself by Captain Blakiston in his gallant attempt to reach Thibet in 1860, viz., by leaving the Yang-tse at the point at which it ceases to be navigable, and taking a course as nearly west as the nature of the country would admit of, by Likiang in 
Northern Yunan to Sudiya on the Brahmaputra. The missionaries report a very superior coal-formation as covering in little disturbed positions the northern half of Yunan, and spreading probably through the extent of the plateau of that province to its southern descent on the Sonkoi, on which M. Dupuis has reported the discovery of coal.

I have now stated, to the best of my ability, the nature of the various routes, the incidents connected with their exploration, and the various opinions entertained of their merits. I shall be happy if the observations I have made have simplified the subject for those who are interested in geographical inquiry, and happier still, if they should be the means of inducing men of influence to visit Burmah. If any should find themselves so disposed, I would recommend them to visit the provinces in November and keep a watch on the Attaran. It will need only a morning's drive from Moulmein town to bring them face to face at the ferry of Nyoung-ben-zeik with troops of hardy Shan pedlars by whom Kong-long, Shunning, Kiengma, Moungting, and Tali, have in all probability been visited within the year. Seeing them, it is difficult not to look forward hopefully to the time when the petty rill of commerce, now filtering through every obstacle that a disorganised and lawless country can present, will by the restoration of order swell into a broad stream of international trade.

As will be readily understood, the task of compressing within the limits of a short paper a subject so widespreading as trade-routes from Western China has been no easy one, and I would ask your indulgence on this ground for the necessary incompleteness of the paper I have written on it.

The President, in inviting a discussion on the subject of the paper, said the Geographical Society had always taken great interest in the subject of the routes between Burmah and China, and had done its best to awaken a similar interest in the public. Such an interest he thought did exist, but the whole question was still very far from being well understood.

Mr. T. T. Cooper said that from Burmah to China viä Bhamo, the trader has to cross three large watersheds, those of the Salween and the Cambodia. The country is extremely mountainous, and but sparsely inhabited by semi-barbarous tribes, who have not a very keen appreciation of the blessings of civilisation following on trade, but are nevertheless somewhat given to a little peddling. Mr. Coryton bad omitted one point of great importance in dealing with the question of the trade-routes. To warrant any expectation of a large trade, a numerous population is necessary; but although the province of Yunan is undoubtedly rich in minerals, the soil fertile, and the people industrious, internecine warfare has so diminished their numbers, that at the present time grass and ruins may be said to cover the luxuriant soil of the country. Hereafter, when the great vitality, which is characteristic of the Chinese, shall have had time to assert itself, and emigrations shall have taken place from the north-eastern provinces to the more fertile west, trade may be expected to arise between Burmah and Yunan. He did not, however, believe 
that this would happen during the present generation. The geography of the country between Manwyne and Bhamo is very interesting. The mighty rivers which flow through the wall-like mountains, and the hills which afford a habitation to the semi-barbarous tribes, are very beautiful. The flora of " those hills is purely tropical, the bamboo being most conspicuous. In the higher altitudes, however, many English shrubs and trees are found, such as the gooseberry, the strawberry, and the oak. The fauna is peculiar to thosehills. There are animals there which are to be found in no other part of the world, the most conspicuous being the Takin, belonging to the deer family, and the Mhitton, a sort of wild cattle, somewhat resembling a cross between the buffalo and the bull. Mr. Coryton, most likely inadvertently, referred to the Shans as a barbarous people; but they have a literature probably as. ancient as that of the Chinese themselves. They were the people who first forged the link of trade between China and Burmah. They, however, were to blame for having introduced the poppy from Burmah into China. Until they introduced it to the Chinese merchants who visited Yunan annually, poppy cultivation and consumption was unknown in the west of China.

Sir George CampBell said the country had sustained a great misfortune in the loss of that enterprising and excellent young man, Mr. Margary, while he himself had publicly to deplore the death of Lieut. Holcombe, who had fallen, with eighty other British subjects, whilst engaged in the exploration of the country between Assam and Burmah. As Mr. Coryton had said, the routes from Assam to Burmah were of only secondary interest until free communication was established between Bhamo and China. What Mr. Cooper had said of the depopulated state of Yunan, showed how advisable it was to. direct attention at present chiefly to the more northerly route, by which direct communication might be obtained with the large and important province of Sze-chuen by way of Batang. The late Duffla Expedition had obtained considerable information with regard to the hill-country to the north of Assam, but the tribes there were very barbarous. The route by the Mishmee country was so far well known, that only political obstacles now intervened to prevent direct communication between Assam and Batang, and through Batang with. China. Of late years a very much greater intimacy than formerly existed, had sprung up between the English and the frontier tribes, and the Mishmees. had become amenable to British authority to a great extent, so that there would be no serious difficulty to encounter in sending travellers through their. country, if the Chinese would only let them pass on the other side. The policy of the Chinese was that of exclusion; but if through the influence of the British Resident at Pekin, or in any other way, permission could be obtained from the Chinese for travellers to enter by the Mishmee route, a communication could be established with the province of Sze-chuen.

Sir Rutherford Alcock thought there were many cases in which it was impossible to separate geographical from political considerations, and the question of a trade-route between India and China was just such a case. Sir GeorgeCampbell had justly said that, as regards access to the richest and wealthiest. part of China, Sze-chuen, through the Mishmee country, the difficulties presented by the physical character of the country were as nothing compared with those caused by the exclusive policy of the Chinese, and their determination, so far as England was concerned, to prevent entry into their country except by the seaboard. There could be no doubt that, quite consistently with international rights and law, England could say to the Chinese Government, "We. have a treaty of amity and commerce with you, by which we have free access. to the interior of your country from the seaboard; and it is an act of hostility on your part to peremptorily forbid us access from every other direction." This was a ground of complaint which might be very fairly taken wheneverHer Majesty's Government thought the time was come to press their rights. 
The late tragic incident only showed with greater certainty, if such proof were needed, that both on the part of Burmah and of China there was a decidedly hostile animus, and a determination per fas aut nefas, by force or diplomacy, to prevent England from gaining any fresh access into the interior of China, or opening any trade-routes in that direction. Mr. Margary was personally known to him (Sir R. Alcock), and there was no more promising officer in the Consular service. Everyone who knew him must lament that he should have fallen in what was a perfectly hopeless effort, under present circumstances, to penetrate through the hill-tribes occupying the border lands between Burmah and China. Those tribes recognised the authority of China, Burmah, or Siam, whenever they were in danger of punishment, but at other times they were independent of all control; and it would be as difficult to hold Pekin responsible for anything they did, as to show that Burmah had any direct action in the unfortunate events that had taken place. During the last twenty years a great deal had been said about the importance of opening traderoutes between Burmah and China; but the tragic incidents which had occurred showed that the British Government, as an Asiatic power, should be very careful how they entered upon such expeditions. In other countries it might be advisable to risk valuable lives for an adequate object, if failure merely meant the failure of that particular enterprise; but England could not afford to risk a failure among Asiatics. Our empire there was an empire of prestige, and it was absolutely essential that we should not accept defeat, or permit a rebuff. He could therefore well understand the reticence that had been shown by successive Governments in India on these matters. If the merchants and pamphleteers who were so eager to urge on the Government to these risky explorations, would regard the difficulties in the proper light, they would not be so ready always to blame those who hesitated before undertaking such expeditions.

The President agreed in the main with Sir Rutherford Alcock's remarks, but not entirely. England must risk something, and, on the whole, both from feeling and experience, he would rather be over-risky than over-cautious. No doubt there were serious considerations to be taken into account, and it behoved a Government to feel its way as much as possible; but he conld not feel at all dispirited or discouraged by what had taken place recently. No doubt the loss of Mr. Margary was a very melancholy affair; but the Chinese Government had accepted the mission, and given every facility in their power for its passage through the country. Mr. Margary had actually passed through the length and breadth of China by the very same route which the mission was to follow subsequently. Some of his letters written by him after his arrival at Bhamo had already been published in 'The Times,' and in the last letter, dated January $17 \mathrm{th}$, after he had apparently passed through all his dangers, and had joined Colonel Brown's party at Bhamo, he expressed the greatest joy at the happy result of his journey. It was very sad to reflect that within a week of that time he was no more, and everyone must sympathise with his bereaved family, and deplore the irreparable loss which not only they, but the public service had sustained. With regard to the traderoutes, although those to the east might be the easiest available for commerce, still they could never compete with those to the west, because these latter avoid all the dangers of the Chinese seas to which the eastern routes are exposed. At present the French had two routes at their disposal, one from the north of Tonquin up the Songka River, and the other from Saigon up the Cambodia River; but after arriving at the embouchure of either of those rivers, the trade would have to encounter the danger of the Chinese seas. The essential object must be to start from the Bay of Bengal, and therefore the great question was whether the route should be by the Irrawady or the Salween. Mr. Coryton had stated that the Salween is not navigable; con- 
sequently, until a railroad was formed in that direction, that route was out of the question. At present the Irrawaddy, however, could be ascended by steamboats without any difficulty as far as Bhamo, and from there to Mômein, the key of Yunan, the distance was only 120 miles. Major Sladen calculated that it could not be more than 130 miles by a circuitous railway. That route accordingly appeared to be the most practicable; but, on the other hand, the tribes inhabiting the Kachyen Hills were exceedingly troublesome and difficult to manage. Major Sladen had sufficient experience of them formerly, and probably the death of Mr. Margary would be traced to the same source. In the mean time all that could be done was " to labour and to wait." It would of course be injudicious to press matters to an undue limit, but a certain pressure ought to be kept up by public opinion, without which all Governments were apt to go to sleep.

\section{Extracts of Letters from Mr. Margary.*}

“ Teng Yueh Chow, January 5, 1875.

" Here I am at the very end of China, and at the goal I sought. But I am going further. I had not arrived half-an-hour the night before last when a packet was put into my hands, from the Political Agent at Bhamo, announcing that the expedition was not yet started, and I was to join it at Bhamo, if possible, soon after January 1 . As there are seven stages between, and a savage territory, I was obliged to well consider my plans, and it was 3 A.M. of the same night before I had resolved, written, sealed, and directed my answer, and prepared my messenger. The latter, after receiving my instructions, had three hours' nap, and called me at 4 o'clock to receive my final blessing ere he started off with my packet; for I determined to see him depart with my own eyes-and I was asleep again in five minutes. Yesterday I arranged business with the Mandarins, to-day I write letters and engage baggage-animals, and to-morrow I start again for the savage borders four stages off, to await my return messenger. If, as I hope, they have not started from that end, I go on ; if otherwise, I drop back to await their arrival at the conjunction point of the three main routes, for the expedition are to follow a wide détour. I suppose they wish to survey a railway route. This letter will, I hope, go viâa Burmah, and outstrip the last three I sent you from Yun-nan, Ta-Li, and Yung-Chang, on November 29, December 18 and 29, which will drag their slow length along over many broad provinces before they reach the mail steamer at Shanghai. I am at the ancient city of Mômein or 'T'eng-Yueh-Chow. It is in ruins. For only last year this remaining stronghold of the Mahomedan rebels became a scene of slaughter, and by falling into Imperial hands again put an end to the fifteen years' kingdom of 'I'u-Wen Hsin. I visited the Tartar General at Ta-li-fu, in the palace of this late worthy and much-to-be-respected rebel. I have no time, I am sorry to say, for a good long letter; but it is a great comfort to be able to gladden your anxious hearts with even a scrap from these buried wilds, and to be able to avail myself of the short cut through Burmah. You have done the same for me with three delightful letters, which reached me in a large packet from Hankow almost immediately after the one from Bhamo. Dates July 28 and two of August 11. .. . I might have got through two sheets by this time but for interruptions. The Brigadier commanding the centre division of the Army paid me a long visit, and brought his little boy with him. It is customary in China to give presents to children in such cases,

* These letters were addressed to General Margary, father of the traveller, and the extracts were communicated by him to 'The Times' newspaper, in which they appeared on March 17th and 18th. 
and as I am all but cleared out of everything, I was obliged to give the little fellow a pair of tortoise-shell sleeve-links, which seemed to delight him much. I like these military men. They are devoid of that stuck-up pride of the literary Mandarins. I called on the General yesterday, and had a very civil reception. His name is Chiang, and he is much famed for a daring military feat which brought about the fall of Ta-li-fu. I was very curious to see the intrepid man who scaled the rocky heights behind the great city and dropped down in its rear. He has a calm, sphinx-like countenance and a charming smile. Yet this man slew thousands of Mahomedans on that day without quarter. It was his birthday, and he was giving a fête to the people. A singsong was progressing in front of the audience daïs, and I had my interview in the presence of 200 or 300 citizens who thronged the courtyard.

\section{“ Territory of Nan-Tien, Jan. 11, Town of Manwyne.}

"I have travelled four stages further since I wrote the first sheet, through a beautiful valley inhabited by a people called Pa-yi, who are a mixture of Chinese settled here 500 years ago, and the Shans or Laotians, who cover the whole country between Burmah, Siam, Cambodia, and China. Their dress and habits have afforded me intense interest and curiosity. Divided into little principalities, three of which we have visited on our way, they are governed by native Chiefs, under Chinese supervision. In every case I have, of course, been the guest of the Chief, and, owing to their sociable dispositions, enjoyed a good deal of intimacy with their families. The women are not shy, like the Chinese, nor fear to talk with a stranger. Their dress is marvellous. I could not keep my eyes off the strange, picturesque figures that met me at every turn. The marvel consists mainly in their turbans, which outrival the busby of a Grenadier. They rise in concentric folds, backwards from the forehead, and attain a diameter of fully a foot at some height above the head. The head can be seen in the hollow behind, where large silver buttons attach the hair, which is plaited into folds. A neat little dark-blue jacket, fastened at the throat with a broad silver buckle, and short petticoats, tightly folded to the figure, of the same dark material and relieved by a phylactery of red, blue, white, and embroidered panels, give them a neat, homely look. They wear also embroidered shoes, and wrap their ankles and shins in blue embroidered cloth. I spent a whole afternoon surrounded by the male members of the family. They examined all my things, and I learned a good many sentences of their language, which they wrote down for me. They write, like us, from left to right, and the characters have almost a Roman look. The men are light, active, well-made fellows. They wear blue cloth round their shins, and expose the knee in a fashion which at a little distance looks uncommonly like the Highland dress. Sometimes dressed in pure white, with a red girdle, covered with a straw hat like a Leghorn, and carrying a long sword in the belt, they enliven the road with their picturesque attire.

"The earrings of the women are made of silver in profuse variety, and other ornaments of silver adorn both sexes.

"January 12.-I am still waiting my messenger, who ought to arrive tonight. I was quite tired out yesterday, and felt in no mood for writing a good letter. The above hurried account of these interesting people is very unsatisfactory, but you will understand how much I have to do. I was only able to snatch an hour in the afternoon for a stroll through the market. It was frequented by a number of queer little semi-savages from the mountains; most of them were women, and they certainly had a most repulsive scowl on their faces. Colour, cowries, silver ornaments distinguished their attire, and they moved about with a shuffling trot, throwing hurried glances right and left. The men carried javelins, but dressed much like Chinamen. These curious 
creatures inhabit the country lying between this and Bhamo, and the two stages ahead of us are infested by their dangerous presence. I am protected by the Chinese Government and so have nothing to fear. A famous ex-brigand, called Li-Hsieh Tāi, who attacked our last expedition in 1867, has been rewarded lately for his services against the rebels with a military command over all this country. He is here, and I felt much curiosity to see how he would receive me. To my surprise he prostrated himself, and paid me the highest honours. I had a most successful interview. He sent for a few notable townsmen and the chieftain of the savages, and introduced me with the greatest respect. We sat in a small room, badly lighted-quite a conclave -and carried on a regular battery of mutual buttering. Li told them I had come protected by an imperial edict and that they had better take care of me. This morning I went out with my gun to get some exercise, and having bagged half-a-dozen wild ducks, I have just sent a brace to the commander as a present. I took two of my servants, and we had great sport. The river was half a mile wide and full of sandbanks, on which duck rested. The first difficulty was to find a boat, and after searching up and down stream we were fortunate enough to find a diminutive punt under the bank without an owner, and calmly took possession of it; but we could not manage it against the stream with the slender paddle which was attached to it. A native, however, offered to paddle us over, and so, with the present of a little cash, we soon found means to be landed on a sandbank. Kicking off gaiters and boots, I waded about after the duck, and managed to bag a good many. We returned through the motley market with our spoil, and excited quite a sensation. Cries of 'Ah-a-ah!' in the peculiar high-pitched tones of these people greeted me, and they held up their thumbs to express their admiration of such prowess. I have bought one of the jackets worn by the little wild women, but cannot find a petticoat to complete the attire. The villages on this lovely plain are all embowered in groves of feathery bamboos and plantains. The latter are ripe even now, and I can buy any quantity for a couple of copper cash apiece. The weather is as temperate as we could wish. On the third stage to TengYueh we rested at a little village nestled high up in a forest-clad mountain. It had been a long stage and full of magnificent scenery. After threading the long gorge, with a torrent dashing below, we entered a wide plain covered with a two-years' jungle growth, and crossed the Mekong River by an elegant suspension bridge. Darkness overtook us just as we began to mount up the steep, paved path which scaled the opposite mountain. Hastily procuring rough torches of straw, bound in sheaves of upwards of $10 \mathrm{ft}$. long, we found our weary way up the interminable staircase for fully two hours, not daring to stop for fear of our lamps not lasting. The latest spark expired as we woke up the village with our shouts. The valley below, as we zigzagged up the slope, presented a lovely illumination. The returning peasants were burning away the jungle from their long neglected fields. One of my men carelessly set light to the parched-up grass alongside our path, and immediately it blazed away down the hill, involving, I fear, many a young tree in ruin. Our Eyrie Rest could only boast of two or three simple huts, and we had missed the way to the Temple where they told us quarters could be found. It was fortunate we had, as on visiting it next day I found an open ruin. Chinese officials, however, had to put up in its dilapidated sheds. A fearful wrangling ensued, which I put a stop to by taking possession of a hut, which turned out to be a newly-erected one. We slept very comfortably, although the walls were only bamboo laths. Next day being New Year's Day, and, curiously enough, our not being able to procure carriers, caused us to stay in this lovely spot, and I resolved to rummage the forest for the game.

"Taking Bombagine (his faithful servant) and a boy to carry the provisionbasket, I plunged into a wood-cutter's path, which soon came to an end, and we 
forced our way through jambrake breast high. All of a sudden an infernal noise woke the primeval echoes, and came nearer and nearer. Bombagine thought it might be a tiger, though it was as much like a feline roar as a trumpet to a whole brass band. It was more of a howl. I was not very well, and consequently nervous. I could hear my heart beating in the stillness, and felt quite annoyed at it. Eagerly watching for the coming beast, we stood on the qui vive. A heavy tread, as of some animal angrily striking the ground, was clearly audible. Just as I was preparing for a shot, however, the beast moved off, and, though we followed, none of us caught a glimpse of the mystery. J have not time to record any more of the numerous incidents that occurred. You must kindly wait until the journal is complete. It has already attained to three volumes of foolscap. I don't remember whether I have mentioned sur goat before. Miles away back, at a now distant city, a Mandarin gave me a goat for food, but I saved it from the butcher's knife, and it has trotted along ever since, repaying us with much diversion. If I take a stroll it likes to accompany me. One day he ate up several orchids I had gathered with some trouble out of the forest, and the poor beast suffered two whole days for his folly. It was amusing to see my men petting it; they put it in a basket and made two coolies carry it. I mean to buy a monkey for it to carry on its back."

\section{"Bhamo, Jan. 17, 1875.}

" You will, no doubt, be surprised to find me in so advanced a position. But here I am safe and sound, and the first European who has travelled through the trade-route of the future. They sent me a Burmese guard of forty men, who conducted me through the savage Kachyen hills, and when we debouched on to wide, flat Burmese plains, covered with jungle and forest, on the 15th, just as the setting sun was bathing the wide expanse in colours, and the new life and semi-Indian manners and customs of the Burmese burst upon us as we rapidly trotted through their picturesque and homely villages, a delightful sense of relief and pleasure came over me and my Chinese companions alike. We slept in a Burmese bamboo cabin perched on hills, and next day floated down the river to Bhamo. It was one of the most delightful periods of my life to come in sight of the British flag again, and soon to be congratulated by a distinguished group of Indian officers on my 'splendid journey.' Colonel Horace Brown is a fine-looking man, with a heavy moustache and imperial. Dr. Anderson has the kindly manners of a savant, and I look forward with intense pleasure to spending hours in such intelligent company. We have an officer with a guard of five Sikhs, and a host of baggage animals and countless stores. The steamers are going soon and I am pressed for time, so can only add a sort of 'latest intelligence.' We shall follow a long round, I expect, and very much doubt if May will nearly put an end to my long travels. I am the picture of health, as people tell me, and you may imagine how full of delight I am at the happy result of my journey and the glowing prospect ahead." 